\title{
LIVROS DIDÁTICOS DE BIOLOGIA E A HISTÓRIA DA CIÊNCIA
}

\author{
Jéssica Zauza Fiorese* \\ Nadir Castilho Delizoicov**
}

Resumo: O presente trabalho apresenta resultados de uma pesquisa que envolveu o livro didático de Biologia e a História da Ciência (HC). A escolha do tema baseou-se na importância dos livros didáticos para professores e alunos durante o processo de ensino-aprendizagem, bem como na recomendação de documentos oficiais para um ensino contextualizado historicamente, uma vez que essa perspectiva contribui para uma compreensão mais adequada da produção do conhecimento científico. O objeto de investigação constitui-se de uma coleção composta por três livros didáticos de Biologia. A coleta de dados ocorreu por meio de uma ficha elaborada para essa finalidade. Os resultados mostraram que ainda é tímida a inserção de uma visão historicamente contextualizada na abordagem dos conteúdos veiculados pelos livros didáticos analisados.

Palavras-chave: Livro didático. História da Ciência. Ensino de Biologia.

\section{Biology textbooks and the History of Science}

Abstract: This paper presents the results of a study of Biology textbooks and the History of Science (HS). The theme was chosen because of the importance of textbooks for teachers and students in the teaching and learning process, and because official documents call for a historically contextualized education, given that this perspective

\footnotetext{
"Licenciada e Bacharel em Ciências Biológicas pela Universidade Comunitária da Região de Chapecó; Avenida Senador Atílio Fontana, 591E, Efapi, 89809-000, Chapecó, Santa Catarina, Brasil; je_fiorese@ unochapeco.edu.br

** Doutora em Educação pela Universidade Federal de Santa Catarina; Professora Titular do Centro de Ciências Humanas e Jurídicas da Universidade Comunitária da Região de Chapecó; Professora colaboradora do Programa de Pós-graduação em Educação Científica e Tecnológica da Universidade Federal de Santa Catarina; Avenida Senador Atílio Fontana, 591 E - Efapi, 89809-000, Chapecó, Santa Catarina, Brasil; ridanc.nadir@gmail.com.br
} 
contributes to a more suitable understanding of the production of scientific knowledge. The object of the study was a collection composed of three Biology textbooks. The data collection involved the use of a form prepared for this purpose. The results of the analysis showed that in the books analyzed a historically contextualized view has only a timid insertion in the approach to the content presented.

Keywords: Textbook. History of Science. Biology education.

\section{INTRODUÇÃO}

O presente trabalho divulga os resultados de uma pesquisa que envolveu o livro didático de Biologia para o ensino médio e a História da Ciência (HC). A escolha do tema baseou-se na importância que os livros didáticos (LDs) tem para professores e alunos durante o processo de ensino-aprendizagem e na recomendação de documentos oficiais para um ensino contextualizado historicamente, uma vez que essa perspectiva, entre outros fatores, contribui para uma compreensão mais adequada sobre a produção do conhecimento científico.

O objeto de investigação constituiu-se de uma coleção composta por três LDs de Biologia, destinada ao ensino médio. A coleta de dados se processou por meio do exame de cada livro da coleção, tendo como parâmetro uma ficha elaborada para essa finalidade (Quadro 1).

Ao longo da análise, procurou-se verificar os seguintes aspectos: quais temas da Biologia apresentam uma abordagem histórica; qual história é "contada" aos alunos, considerando os aspectos internalistas e externalistas da Ciência; qual visão de cientista é veiculada pelos LDs; o modo pelo qual os livros relatam o processo de produção do conhecimento, ou seja, se apresentam controvérsias e dificuldades enfrentadas pelos cientistas durante o processo de elaboração de um conceito e, finalmente, se o trabalho do cientista é apresentado como um empreendimento individual ou coletivo.

Inicialmente discorremos a respeito da importância do LD para o ensino no Brasil. Na sequência, apresentamos as posições de autores que defendem a articulação entre História da Ciência e ensino e, finalmente, os resultados e a discussão da análise realizada. Nas considerações finais há recomendações para incrementar uma perspectiva histórica no ensino de biologia. 


\section{IMPORTÂNCIA DO LIVRO DIDÁTICO PARA O ENSINO}

Os estudos sobre o LD têm sido frequentes na literatura brasileira, conforme testemunham os trabalhos de Pretto (1985), Fracalanza (1993), Delizoicov (1995), Bizzo (1996), Mohr (2000), Megid Neto e Fracalanza (2003), Carneiro, Santos e Mól (2005), Carneiro e Gastal (2005), Gonçalves (2005), Batista, Mohr e Ferrari (2007), Perrelli et al. (2012), Silva e Oliveira (2013), entre outros.

O interesse pelo tema está ligado ao papel atribuído ao livro didático, uma vez que este continua sendo uma das principais ferramentas de auxílio para professores e alunos no processo de ensino-aprendizagem, constituindo, em muitos casos, o único livro ao qual o aluno da educação básica tem acesso.

Os LDs foram compreendidos historicamente como agentes determinantes de currículos, limitando a inserção de novas abordagens e possibilidades de contextualização do conhecimento (BIZZO, 1996). Eles têm acompanhado o desenvolvimento do processo de escolarização no Brasil. Na primeira metade do século passado, era de responsabilidade do professor determinar conteúdos e metodologias de ensino. Porém, nas décadas seguintes, com a democratização do ensino, que possibilitou aos filhos das camadas menos favorecidas da população terem acesso à escolarização, aliada à falta de professores, particularmente para a educação básica, em razão da ampliação de vagas, os conteúdos escolares e os princípios metodológicos passaram a ser veiculados pelos LDs, os quais assumem importante papel na educação formal (FRISON et al., 2009).

Muitos LDs, que por décadas circularam pelas escolas brasileiras, tiveram qualidade questionável, tanto a erros conceituais quanto a preconceitos, ilustrações que induziam a erros, exercícios para mera memorização, entre outros. Com a avaliação dos livros didáticos por especialistas, esses problemas foram sanados ou minimizados. No entanto, há conhecimentos que necessitariam estar presentes no LD com maior ênfase, como, por exemplo, a HC articulada aos conteúdos das ciências naturais, pelas razões expostas mais adiante neste trabalho.

A importância do LD para a educação escolar brasileira é testemunhada por iniciativas do Governo, como o Programa Nacional do Livro Didático (PNLD):

[...] é o mais antigo dos programas voltados à distribuição de obras didáticas aos estudantes da rede pública de ensino brasileira e iniciou-se, com outra denominação, em 1929. Ao longo desses 80 anos, o programa foi aperfeiçoado e teve diferentes nomes e formas de execução. (FUNDO NACIONAL DE DESENVOLVIMENTO DA EDUCAÇÃO, 2012). 
O Decreto-Lei n. 91.542, de 1985, estabeleceu grande parte das características atuais do PNLD, o qual se tornou uma política de Governo e não de Estado. Os critérios para a análise dos LDs submetidos para a avaliação foram se alterando/ aperfeiçoando e, assim, a sua qualidade foi melhorando ao longo do tempo.

Em 2004, foi implantado, pela Resolução n. 38 do FNDE, o Programa Nacional do Livro Didático para o Ensino Médio (PNLEM), visando à universalização de LDs para alunos do ensino médio público de todo o país. Durante o ano 2005, LDs de Biologia e de demais áreas do conhecimento para o ensino médio, publicados no Brasil, foram avaliados (PORTAL EDUCAÇÃO, 2012).

A finalidade foi realizar a análise das coleções submetidas pelas editoras para definir quais atendiam a critérios mínimos de qualidade para serem recomendadas ao Ministério da Educação (MEC), que compra e distribui LDs às escolas públicas. A avaliação é realizada por uma equipe de especialistas recrutados nas universidades brasileiras e acontece cerca de dois anos antes da aquisição dos livros. Essa equipe encarrega-se também da produção de resenhas críticas dos livros recomendados, reunidas em um Guia (GLD) cuja finalidade é orientar o professor para a escolha do livro. $\mathrm{O}$ PNLD e o PNLEM têm alcançado bons resultados no que se refere à melhoria da qualidade dos LDs adquiridos pelo MEC (EL-HANI; ROQUE; ROCHA, 2011).

Esse avanço pode ser observado, por exemplo, ao se examinar a ficha de avaliação dos LDs de Biologia do PNLEM de 2012. No documento, é possível identificar um item no qual há orientação para que os avaliadores observem se a obra contempla a contextualização histórica do conhecimento, conforme é apresentado a seguir:

\begin{abstract}
2.7 Auxilia na construção de uma visão de que o conhecimento biológico e as teorias em Biologia se constituem em modelos explicativos, elaborados em determinados contextos sociais e culturais, superando a visão a-histórica de que a vida se estabelece como uma articulação mecânica de partes. (SECRETARIA DE EDUCAÇÃO BÁSICA, 2011).
\end{abstract}

$\mathrm{Na}$ sequência, apresentamos as posições de pesquisadores que defendem uma abordagem contextualizada historicamente dos conteúdos no ensino-aprendizagem das ciências naturais.

\title{
3 HISTÓRIA DA CIÊNCIA E ENSINO
}

A importância da articulação entre HC e ensino das ciências naturais tem sido defendida por diversos pesquisadores, são exemplos: Peduzzi, Zylbersztajn e Moreira (1992), Slongo (1996), Zanetic (1998), Delizoicov, Carneiro e Delizoicov (2004), 
Scheid, Ferrari e Delizoicov (2005), Delizoicov (2006), Ferrari e Scheid (2006), Martins (2006), Forato, Martins e Pietrocola (2012), entre outros. Esses autores mostram de diferentes maneiras a importância de se considerarem os aspectos histórico-epistemológicos no ensino de Ciências, argumentando que essa inserção, entre outros benefícios, poderá contribuir para que professores e alunos tenham uma melhor compreensão sobre a natureza da Ciência. É essencial o reconhecimento discente e docente de que a Ciência não é neutra, não é estática e fruto de verdades absolutas, mas mutável, provida de alterações advindas de avanços, erros e conflitos (BRASIL, 2011).

A inserção da HC nas aulas, segundo Martins (2006), El-Hani (2006), Martins e Brito (2006), Delizoicov (2006), Ferrari e Scheid (2006), Rosa e Silva (2010), Peduzzi, Martins e Ferreira (2012), contribui para se reconhecer que a Ciência não se faz por ideias espontâneas advindas de "gênios", mas de estudiosos que se dedicaram fortemente à pesquisa. A HC auxilia na construção de uma visão de que as teorias se constituem em modelos explicativos, elaborados em determinados contextos sociais e culturais e são, portanto, provisórios, superando a visão a-histórica da produção do conhecimento. No entanto, com frequência:

A apresentação da ciência é absolutamente a-histórica. Sem referência a seu processo de criação e muito menos ao contexto em que foi criada. E, o que é pior, na tentativa de suprir esta lacuna passa uma visão da História da Ciência como se fosse, como já dizíamos um armazém, um depósito onde se guardam as vidas dos cientistas, seus feitos e suas obras. (PRETTO, 1985, p. 77).

Segundo Martins (2006), a HC pode ser utilizada como um dispositivo didático útil, contribuindo para tornar o ensino da Ciência de nível médio mais interessante e facilitar sua aprendizagem. Isso pode ser aplicado tanto ao ensino da Biologia quanto ao de outras disciplinas. Além disso, de acordo com esse autor, a HC pode fazer mais pelo ensino, como mostrar por meio de episódios históricos o processo gradativo e lento da construção do conhecimento, permitindo que se tenha uma visão mais concreta da natureza real da Ciência, seus métodos e suas limitações, o que possibilitará a formação de um espírito crítico.

De acordo com o PCNEM (BRASIL, 1997, p. 27), “[...] a história das Ciências [...] tem uma relevância para o aprendizado que transcende a relação social, pois ilustra também o desenvolvimento e a evolução dos conceitos a serem aprendidos."

A história das idéias científicas e a história das relações do ser humano com seu corpo, com os ambientes e com os recursos naturais deve ter lugar no ensino, para que se possa construir com os alunos uma concepção interativa de Ciência e Tecnolo- 
gia não-neutras, contextualizada nas relações entre as sociedades humanas e a natureza. (BRASIL, 1997, p. 27).

A inserção da $\mathrm{HC}$ no ensino poderá trazer significativas contribuições como superar a crença de que o homem tem meios de atingir a verdade sem se confrontar com a dúvida e não problematizando o conhecimento (SLONGO, 1996). Situar historicamente a produção do conhecimento proporciona ao aluno compreender que o conhecimento não brotou pronto como, em geral, apresenta-se nos LDs. Estes, de modo geral, costumam veicular apenas os resultados aos quais a Ciência chegou, ao que Sutton (1996) denomina "sistema de rotulação", pois se trata de um processo de simplificação do conhecimento ao se atribuir "rótulos" a conceitos científicos. Os LDs não costumam apresentar aspectos importantes do processo de produção do conhecimento, como:

De que modo as teorias e os conceitos se desenvolvem? Como os cientistas trabalham? Quais as ideias que não aceitamos hoje em dia e que eram aceitas no passado? Quais as relações entre ciência, filosofia e religião? Qual a relação entre o desenvolvimento do pensamento científico e outros desenvolvimentos históricos que ocorreram na mesma época? (MARTINS, 2006, p. 17).

Ainda segundo Martins (2006), a HC procura esclarecer concepções históricas errôneas que vêm sendo perpetuadas ao longo do tempo nos LDs, como, por exemplo, que a Ciência é o resultado da aplicação de um “método científico". Isso não é verdade, uma vez que:

Os pesquisadores formulam hipóteses ou conjunturas a partir de idéias que podem não ter fundamento, baseiam-se em analogias vagas, têm idéias preconcebidas ao fazerem suas observações e experimentos, constroem teorias provisórias [...] discordam uns dos outros [...] lutam entre si para impor suas idéias [...] O processo científico é extremamente complexo, não é lógico e nem segue uma fórmula infalível. Há uma arte da pesquisa, que pode ser aprendida, mas não uma sequência de etapas que deve ser seguida sempre como uma receita de bolo. (MARTINS, 2006, p. 19).

A HC pode mostrar que na produção do conhecimento há disputas entre os pesquisadores, controvérsias e transformações do conhecimento que lançam por terra concepções e teorias as quais eram anteriormente aceitas.

O LD tem negligenciado o valor didático da HC. Nele encontra-se, com frequência, uma HC cronológica que acaba veiculando apenas nomes de cientistas conhecidos, além do que “[...] muitos autores de livros científicos didáticos, 
geralmente com a melhor das intenções, introduzem em suas obras uma série de informações sobre a história da ciência - em geral, [...] completamente errôneas." (MARTINS, 2006, p. 24).

[...] é justamente a pouca presença da História da Ciência nos manuais escolares e o seu uso distorcido no sentido de promover uma reconstrução de idéias que parecem fluir naturalmente em direção a teorias atualmente aceitas [...], ou seja, a imagem do trabalho científico que resulta dessa opção educacional é a de cientistas de épocas anteriores trabalhando linear e cumulativamente em prol de uma ciência em constante desenvolvimento. (PEDUZZI, 2001, p. 153).

Kuhn (2011) adverte que a história linear e cumulativa representada nos manuais faz com que as mudanças ocorridas na Ciência sejam tratadas não como revoluções, quebras, mas como meras adições ao que já havia antes. A história passada é transmitida a partir de uma lente focada no presente, o que faz com que:

[...] os cientistas de épocas anteriores são implicitamente representados como se tivessem trabalhado sobre o mesmo conjunto de problemas fixos e utilizado o mesmo conjunto de cânones estáveis que a revolução mais recente em teoria e metodologia científica fez parecer científicos. (KUHN, 2011, p. 177-178).

Nem sempre os LDs se dedicam a articular o desenvolvimento da Ciência com fatores sociais, políticos, econômicos, religiosos, culturais, ideológicos, entre outros. São fatores externos à comunidade científica, mas que têm grande influência no fazer científico. Geralmente nos livros didáticos encontra-se apenas uma visão internalista da Ciência, ou seja, priorizam conteúdos intrínsecos ou cognitivos da própria Ciência.

Segundo Oliveira e Silva (2012), a perspectiva internalista da Ciência refere-se ao desenvolvimento de seus próprios objetos, leis, métodos e processos, já a perspectiva externalista é compreendida como uma atividade inserida no conjunto mais amplo de todas as atividades humanas. "Ao estudar a Ciência de uma determinada época há que estudar a estrutura social, a relação das classes, o modo de produção, a personalidade dos cientistas, os sistemas artísticos e culturais dessa época." (OLIVEIRA; SILVA, 2012, p. 45).

De acordo com Oliveira e Silva (2012, p. 43):

Lakatos (1987) afirma que qualquer reconstrução racional (interna) da história da ciência deve ser complementada com uma história externa (sociopsicológica), que explica os fatores não racionais presentes na construção do conhecimento científico. Ele afirma que a historiografia da ciência, seja ela interna ou ex- 
terna, é que determina os problemas que serão analisados pelo historiador. Lakatos (1987) apresenta a abordagem Internalista como primária e a Externalista como secundária, já que as problemáticas da historiografia externa são definidas a partir da historiografia interna. Tal afirmação vem do fato que o aspecto racional do desenvolvimento científico só pode ser explicado por meio da própria lógica do desenvolvimento científico.

Em suma, a abordagem histórica Internalista, de acordo com Oliveira e Silva (2012), analisa o conteúdo conceitual da Ciência e a abordagem Externalista é aquela que se preocupa com aspectos extracientíficos, presentes no desenvolvimento do conhecimento científico. Para esses autores, ao se descrever a Ciência abordando somente a visão internalista não se esclarecerão os aspectos externos relevantes para um bom entendimento dos fatores que contribuíram para a construção científica.

Na sequência, apresentamos os resultados e a análise dos dados coletados.

\section{PROCEDIMENTOS METODOLÓGICOS}

A pesquisa aqui relatada é de natureza qualitativa (MINAYO, 2011) do tipo bibliográfica. $\mathrm{O}$ objeto de estudo se constitui em uma coleção composta por três livros didáticos de Biologia destinada ao ensino médio. A opção pela coleção selecionada ocorreu pelo fato de esta ser utilizada por professores e alunos de uma das maiores escolas públicas da região Oeste de Santa Catarina.

De acordo com o Guia de Livros Didáticos (GLD), do PNLD (2012), a coleção selecionada para a análise está estruturada em três volumes e organizada por unidades e capítulos. Os capítulos são compostos por seções que abordam itens específicos do tema. No início de cada capítulo, pequenos textos apresentam resumidamente a ideia central de cada seção. Ao final dos capítulos, são apresentados dois tipos de atividades de avaliação: "Questões para pensar e discutir" - são atividades e pesquisas para a discussão dos assuntos; "Vestibulares pelo Brasil" - apresenta questões de vestibulares do país. Os capítulos, em sua maioria, apresentam um quadro denominado "Ciência e Cidadania", no qual são apresentados textos com assuntos que relacionam a "Ciência com o cotidiano", acompanhado de um guia de leitura para orientar o estudo. Ainda segundo o GLD, “[...] a obra apresenta uma visão correta, atualizada e ampla da Biologia para o ensino médio, possibilitando aos alunos uma aprendizagem dos conhecimentos básicos da Biologia." (FUNDO NACIONAL DE DESENVOLVIMENTO DA EDUCAÇÃO, 2012). 
Os LDs foram examinados e a coleta de dados se deu mediante a utilização de uma ficha adaptada de Batista, Mohr e Ferrari (2007), para este estudo, conforme segue:

Quadro 1 - Ficha de análise

\begin{tabular}{|c|c|c|c|}
\hline \multicolumn{4}{|c|}{ Capítulo p. $\mathrm{x}$ a $\mathrm{x}$} \\
\hline Subtítulo do capítulo $\mathbf{p} x$ & & Seções & \\
\hline \multirow{4}{*}{ Perfil do Cientista } & Nome & & \\
\hline & $\begin{array}{l}\text { Data de nascimento } \\
\text { e falecimento }\end{array}$ & & \\
\hline & $\begin{array}{l}\text { Nacionalidade e/ou } \\
\text { local de nascimento } \\
\text { e/ou local que } \\
\text { desenvolveu seu } \\
\text { trabalho }\end{array}$ & & \\
\hline & $\begin{array}{l}\text { Tipo de formação } \\
\text { e/ou instituição de } \\
\text { ensino }\end{array}$ & & \\
\hline \multirow[t]{3}{*}{$\begin{array}{c}\text { Períodos de dedicação } \\
\text { Produção do } \\
\text { Conhecimento } \\
\end{array}$} & \multirow{3}{*}{$\begin{array}{l}\text { Característica da } \\
\text { atividade científica }\end{array}$} & $\begin{array}{l}\text { Com controvérsias } \\
\text { e/ou rupturas }\end{array}$ & \\
\hline & & $\begin{array}{l}\text { Ciência como } \\
\text { atividade individual }\end{array}$ & \\
\hline & & $\begin{array}{l}\text { Ciência como } \\
\text { atividade coletiva }\end{array}$ & \\
\hline \multirow{4}{*}{ Ilustrações/Imagens } & Figuras de cientista & & \\
\hline & $\begin{array}{l}\text { Figuras das etapas } \\
\text { de um experimento } \\
\text { e/ou de figuras } \\
\text { de máquinas e/ } \\
\text { ou figuras de } \\
\text { equipamentos }\end{array}$ & & \\
\hline & Modelos & & \\
\hline & $\begin{array}{l}\text { Figuras que } \\
\text { relacionam o } \\
\text { cotidiano com } \\
\text { modelos originais }\end{array}$ & & \\
\hline
\end{tabular}




\begin{tabular}{|c|c|c|c|}
\hline \multirow[b]{4}{*}{$\begin{array}{l}\text { Tipo de Textos ou } \\
\text { Documentos }\end{array}$} & Textos adaptados & & \\
\hline & Anedotas & & \\
\hline & Notas & & \\
\hline & $\begin{array}{l}\text { Outros } \\
\text { (representações } \\
\text { esquemáticas, selos, } \\
\text { poemas, pinturas, } \\
\text { etc.) }\end{array}$ & & \\
\hline \multirow{3}{*}{ Contextualização } & Social & & \\
\hline & Político & & \\
\hline & Religioso & & \\
\hline \multirow{9}{*}{ Atividades } & \multirow{4}{*}{$\begin{array}{l}\text { Presença da } \\
\text { Atividade }\end{array}$} & Sim & \\
\hline & & Não & \\
\hline & & \multirow[t]{2}{*}{ Leitura dirigida } & $\begin{array}{l}\text { No próprio livro } \\
\text { didático }\end{array}$ \\
\hline & & & Em outras fontes \\
\hline & \multirow{3}{*}{ Tipo da atividade } & Pesquisas escolares & \\
\hline & & $\begin{array}{l}\text { Análise de dados } \\
\text { históricos }\end{array}$ & \\
\hline & & $\begin{array}{l}\text { Reprodução de } \\
\text { experimentos } \\
\text { históricos }\end{array}$ & \\
\hline & \multirow{2}{*}{$\begin{array}{l}\text { Proposta para } \\
\text { realização }\end{array}$} & Individual & \\
\hline & & Em grupo & \\
\hline \multirow{3}{*}{$\begin{array}{c}\text { Classificação do } \\
\text { tema quanto ao } \\
\text { desenvolvimento da } \\
\text { história da Ciência }\end{array}$} & Informação histórica & & \\
\hline & $\begin{array}{l}\text { Trecho da História } \\
\text { da Ciência }\end{array}$ & & \\
\hline & História da Ciência & & \\
\hline \multirow{2}{*}{$\begin{array}{c}\text { Papel da História da } \\
\text { Ciência }\end{array}$} & Fundamental & & \\
\hline & Complementar & & \\
\hline Observação & & & \\
\hline
\end{tabular}

Fonte: adaptado de Batista, Mohr e Ferrari (2007).

Nesse instrumento foram priorizados os seguintes dados:

a) perfil do cientista - identificando o nome do pesquisador apresentado, a data de nascimento e morte, nacionalidade e local onde desenvolveu a pesquisa, sua formação e período de dedicação ao trabalho; 
b) produção do conhecimento - explicitando o modo como a obra apresenta as características da atividade científica, com destaque para a individualidade ou coletividade da produção e para a existência de controvérsias e rupturas no processo de seu desenvolvimento;

c) características das ilustrações/imagens - descrevendo as figuras dos cientistas, as ilustrações das etapas dos experimentos ou, ainda, figuras de máquinas e equipamento e figuras que relacionam o cotidiano com modelos originais;

d) tipologias dos textos ou documentos - verificando se os textos históricos são adaptados, em forma de anedotas, notas ou em forma de selos, poemas, pinturas e representações;

e) contextualização dos fatos - identificando aspectos sociais, políticos ou religiosos envolvidos na história apresentada pela obra;

f) atividades sugeridas - no próprio livro didático ou em outras fontes, o tipo de atividade proposta e o modo de realização;

g) classificação do texto quanto ao desenvolvimento da $\mathrm{HC}$ - informação histórica, trecho da $\mathrm{HC}$ e contextualização histórica de algum conceito;

h) papel da $\mathrm{HC}$ - como fundamental ou complementar.

O instrumento de coleta de dados assim organizado permitiu responder às questões de pesquisa anunciadas na introdução deste trabalho: quais temas da Biologia apresentam uma abordagem histórica; qual história é "contada" aos alunos, considerando seus aspectos internalistas e externalistas da Ciência; qual visão de cientista é veiculada pelos LDs; qual o modo pelo qual os livros relatam o processo de produção do conhecimento, ou seja, se apresentam controvérsias e dificuldades enfrentadas pelos cientistas durante o processo de elaboração de um conceito e, finalmente, identificar se o trabalho do cientista é apresentado como um empreendimento individual ou coletivo.

Os dados coletados foram analisados segundo a perspectiva da análise de conteúdo de Bardin (1979). Foram utilizadas 80 fichas, sendo 34 relacionadas ao volume 1 da coleção, 16 ao volume 2 e 30 relacionadas ao volume 3 . Os resultados e a análise dos dados são apresentados na sequência. 


\section{RESULTADOS E DISCUSSÃO}

\subsection{PRESENÇA DA HC NOS LDs DE BIOLOGIA}

Com o objetivo de observar a presença da HC nos LDs de Biologia, elaborou-se o Quadro 2 com os dados encontrados na coleção selecionada.

Quadro 2 - Temas que apresentam a HC nos LDs de Biologia

\begin{tabular}{|c|c|c|}
\hline V. 1 Biologia das células & V.2 Biologia dos organismos & V. 3 Biologia das populações \\
\hline A origem da Biologia & $\begin{array}{l}\text { Breve história da classificação } \\
\text { dos seres vivos }\end{array}$ & $\begin{array}{l}\text { Os filósofos gregos e a here- } \\
\text { ditariedade }\end{array}$ \\
\hline Hipócrates & A classificação de Aristóteles & $\begin{array}{l}\text { Pré-formação } \\
\text { epigênese }\end{array}$ \\
\hline Aristóteles & $\begin{array}{l}\text { O sistema de classificação de } \\
\text { Lineau }\end{array}$ & A descoberta dos gametas \\
\hline $\begin{array}{l}\text { O racionalismo na Idade Mé- } \\
\text { dia }\end{array}$ & Categorias taxonômicas & $\begin{array}{l}\text { Descoberta dos cromossomos } \\
\text { e das divisões celulares }\end{array}$ \\
\hline A revolução científica & $\begin{array}{l}\text { É possível conceituar espécie } \\
\text { biológica? }\end{array}$ & A descoberta da meiose \\
\hline $\begin{array}{l}\text { Uma nova forma de estudar } \\
\text { a natureza }\end{array}$ & Conceito biológico de espécie & $\begin{array}{l}\text { A importância de Mendel para } \\
\text { a genética }\end{array}$ \\
\hline O método hipotético dedutivo & $\begin{array}{l}\text { Filogenias ou árvores } \\
\text { filogenéticas }\end{array}$ & $\begin{array}{l}\text { Bases celulares da segregação } \\
\text { dos fatores genéticos }\end{array}$ \\
\hline $\begin{array}{l}\text { Falseabilidade de uma hipó- } \\
\text { tese }\end{array}$ & Sistemática filogenética & $\begin{array}{l}\text { Os conceitos de genótipo e } \\
\text { fenótipo }\end{array}$ \\
\hline $\begin{array}{l}\text { Teoria, hipótese e lei da Ci- } \\
\text { ência }\end{array}$ & As diferentes classificações & $\begin{array}{l}\text { Sistemas ABO de grupos san- } \\
\text { guíneos }\end{array}$ \\
\hline O que é vida? & $\begin{array}{l}\text { Absorção de água e sais } \\
\text { minerais pelas plantas }\end{array}$ & $\begin{array}{l}\text { A teoria cromossômica da he- } \\
\text { rança }\end{array}$ \\
\hline $\begin{array}{l}\text { Variabilidade genética, sele- } \\
\text { ção natural e adaptação }\end{array}$ & Condução de seiva mineral & A hipótese de Sutton e Boveri \\
\hline $\begin{array}{l}\text { A teoria da geração espontâ- } \\
\text { nea }\end{array}$ & Anéis de Malpighi & $\begin{array}{l}\text { Exemplo clássico de herança } \\
\text { quantitativa }\end{array}$ \\
\hline O experimento de Redi & Condução de seiva orgânica & $\begin{array}{l}\text { A natureza química do mate- } \\
\text { rial }\end{array}$ \\
\hline O experimento de Joblot & Giberelinas & O código genético \\
\hline Needham versus Spallanzani & $\begin{array}{l}\text { Luz e floração/fotoperiod- } \\
\text { ismo }\end{array}$ & $\begin{array}{l}\text { Diferenças entre genes bacte- } \\
\text { rianos e eucarióticos }\end{array}$ \\
\hline
\end{tabular}




\begin{tabular}{|c|c|c|}
\hline $\begin{array}{l}\text { Pasteur e a derrubada da } \\
\text { abiogênese }\end{array}$ & Diversidade dos artrópodes & Heterose ou vigor híbrido \\
\hline $\begin{array}{l}\text { A invenção da indústria dos } \\
\text { enlatados }\end{array}$ & & Enzimas de restrição \\
\hline A origem da pasteurização & & Clonagem molecular do DNA \\
\hline $\begin{array}{l}\text { Caçadores de micróbios } \\
\text { promovem avanços na Me- } \\
\text { dicina }\end{array}$ & & $\begin{array}{l}\text { Ideias evolucionistas de La- } \\
\text { marck }\end{array}$ \\
\hline A formação da Terra & & $\begin{array}{l}\text { Ideias evolucionistas de Dar- } \\
\text { win }\end{array}$ \\
\hline $\begin{array}{l}\text { Panspermia e evolução quími- } \\
\text { ca }\end{array}$ & & $\begin{array}{l}\text { A viagem de Darwin ao redor } \\
\text { do mundo }\end{array}$ \\
\hline $\begin{array}{l}\text { Quais eram as condições da } \\
\text { Terra primitiva? }\end{array}$ & & O conceito de seleção natural \\
\hline $\begin{array}{l}\text { Primeiros vestígios de vida na } \\
\text { Terra }\end{array}$ & & $\begin{array}{l}\text { Determinando a idade de um } \\
\text { fóssil }\end{array}$ \\
\hline O experimento de Miller & & Mimetismo \\
\hline O mundo do RNA & & $\begin{array}{l}\text { O conceito de espécie bioló- } \\
\text { gica }\end{array}$ \\
\hline Origem da célula eucariótica & & $\begin{array}{l}\text { Documentário fóssil da histó- } \\
\text { ria humana }\end{array}$ \\
\hline $\begin{array}{l}\text { Microscópio simples e com- } \\
\text { posto }\end{array}$ & & O que é ecologia? \\
\hline Origem do termo "célula" & & $\begin{array}{l}\text { Populações, comunidades e } \\
\text { ecossistemas }\end{array}$ \\
\hline Teoria celular & & $\begin{array}{l}\text { O principio da exclusão com- } \\
\text { petitiva }\end{array}$ \\
\hline Partes fundamentais da célula & & $\begin{array}{l}\text { O conceito de capacidade de } \\
\text { suporte }\end{array}$ \\
\hline \multicolumn{3}{|l|}{ O núcleo celular } \\
\hline \multicolumn{3}{|l|}{ Etapas da fotossíntese } \\
\hline \multicolumn{3}{|l|}{ A descoberta do DNA } \\
\hline $\begin{array}{l}\text { Duplicação semiconservativa } \\
\text { do DNA }\end{array}$ & & \\
\hline
\end{tabular}

Fonte: os autores.

No volume 1, denominado "Biologia das células", foi possível observar temas que abordam fragmentos da HC. Entre eles destaca-se "A origem do racionalismo".

Há cerca de 2.500 anos, alguns sábios gregos deram um passo fundamental para o surgimento e o desenvolvimento da ciência 
ao fazer uma distinção entre o estudo da natureza e as questões religiosas. Nasceu assim o pensamento naturalista, que tentava explicar os fenômenos naturais com base em fatos e processos da própria natureza, e não em termos místicos e sobrenaturais, como se costumava fazer nas sociedades antigas. $\mathrm{O}$ pensamento naturalista desenvolveu-se entre os séculos VII e IV a.C. em Jônia [...] Os filósofos jônios foram os primeiros a valorizar explicações naturais para os fenômenos físicos, tendo por base a observação dos fatos e o pensamento racional. Admite-se que Tales de Mileto (624-548 a.C.) foi um dos fundadores desse tipo de filosofia da natureza, que ficou conhecida como ciência grega. (AMABIS; MARTHO, 2010a, p. 19).

Nota-se, na citação, a preocupação dos autores em apresentar ao aluno as bases do pensamento naturalista que fundamentou o que foi denominado ciência grega, surgida em determinado contexto histórico e cultural.

Ainda no volume 1, os autores abordaram temas que foram alvo de grandes discussões na comunidade científica ou de grandes avanços do conhecimento, como é o caso da teoria da geração espontânea que, a partir do século XVIII, gerou debates sobre a origem da vida na Terra, o que contribui para que o aluno possa compreender que o desenvolvimento do conhecimento não é linear, mas avança por transformações e rupturas com o que está posto.

Fleck (1986) adverte que conflitos de ideias, contradições, diferenças de ponto de vista, divergências e controvérsias são características do período que antecede a transformação de um estilo de pensamento, o que leva à substituição da teoria dominante.

Os experimentos do pesquisador francês Louis Pasteur, que sepultaram a ideia de que seres vivos podiam surgir por geração espontânea; e a teoria evolucionista do cientista Charles Darwin, segundo a qual os primeiros seres vivos surgiram num passado remoto e desde então evoluíram, originando a variedade de seres atuais. (AMABIS; MARTHO, 2010a, p. 43).

Esse exemplo citando Pasteur e Darwin contribui para que o aluno possa compreender que não há verdades absolutas, o conhecimento é provisório e pode ser substituído por outro que se adapta melhor aos problemas colocados.

Nos demais subtítulos do volume 1, observam-se informações a respeito da biologia celular e pequenos trechos da $\mathrm{HC}$, complementando o assunto apresentado no texto principal, conforme exemplo a seguir:

Um dos últimos pesquisadores do mundo antigo a realizar estudos importantes sobre os seres vivos foi o médico greco-romano Galeno (130-200 d.C.), que viveu em Roma e atuou como cirurgião de gladiadores. Apesar da prática habitual dos cruéis e sangrentos combates nas arenas, os romanos proibiam a disse- 
cação de cadáveres; Galeno só tinha oportunidade de observar a anatomia humana nos gladiadores feridos que tratava. Grande parte de seus estudos anatomicos fundamentam-se em dissecações de animais, como cachorros, ovelhas e macacos. Com base nesses estudos, Galeno escreveu uma extensa obra sobre anatomia e fisiologia humanas. Apesar de apresentar vários erros, decorrente, sobretudo da impossibilidade de estudar diretamente o corpo humano, essa obra exerceu influência na Medicina até o século XVI. (AMABIS; MARTHO, 2010a, p. 21).

Nessa citação, pode-se observar que na produção do conhecimento ocorrem limitações decorrentes de fatores ligados à forma de pensar de determinada época, o que levou ao desenvolvimento de uma anatomia comparada, pois na Idade Média a anatomia humana era considerada uma prática pagã.

Apesar dos erros de Galeno, reconhecidos posteriormente, seus escritos perduraram por cerca de 1500 anos, constituindo um estilo de pensamento (FLECK, 1986) que orientou a formação de médicos daquela época. Isso pode ajudar os alunos a compreenderem que há dificuldades na produção do conhecimento, as quais podem induzir a erros e cujo reconhecimento como tais pode levar anos.

No volume 2, "Biologia dos organismos", estão presentes os seguintes temas: sistemática e classificação biológica, botânica, zoologia e anatomia. Algumas informações podem ser consideradas ligadas à $\mathrm{HC}$, por exemplo, na abordagem da sistemática.

O filosofo grego Aristóteles [...], foi pioneiro em classificar os seres vivos. Em um de seus trabalhos, ele demonstra um visão avançada da classificação biológica ao destacar a importância da organização corporal dos animais como critério para dividi-los em grupos, ideia que só foi retomada mais de 2 mil anos depois, por Lineu [...] (AMABIS; MARTHO, 2010c, p. 19).

O professor pode desepertar a atenção do aluno para o fato de que o conhecimento sobre a classificação biológica, iniciada por um estudioso, foi retomada e serviu de base para estudos posteriores, testemunhando que o desenvolvimento do conhecimento é coletivo e não fruto de um indivíduo, como se fosse um "gênio", ainda que isso tenha demorado aproximadamente dois mil anos. O professor poderá, ainda, problematizar o fato, levando os alunos a levantarem hipóteses a respeito das causas históricas desse longo espaço para a transformação do conhecimento.

Em outro breve relato, pode-se observar a gênese da classificação biológica, sugerida primeiramente por Aristóteles e, dois mil anos depois, por Lineu. Esse texto é geralmente comum em LDs de biologia para o ensino médio.

No volume 2, encontram-se informações históricas, conforme o exemplo a seguir: 
O desenvolvimento da Biologia na primeira metade do século XX revelou a necessidade de separar os seres vivos em novos reinos. Em 1937, o biólogo francês Edouard Chatton (18831947) chamou a atenção para o fato de as bactérias apresentarem células procarióticas, isto é, sem núcleo nem organelas membranosas, enquanto todos os outros seres vivos possuem células eucarióticas. Essa diferença levou alguns biólogos a propor a separação das bactérias em um reino exclusivo o qual denominaram Monera, termo utilizado anteriormente para designar uma das divisões do reino Protista, proposto por Haeckel em 1866. (AMABIS; MARTHO, 2010c, p. 37).

$\mathrm{Na}$ citação anterior, o professor poderá despertar atenção do aluno para observar que o conhecimento científico sofre alterações ao longo do tempo, particularmente quando novos problemas propõem desafios que, para serem enfrentados, exigem novos estudos e conhecimentos.

O volume 3, "Biologia das populações", contém temas que geraram grandes discussões e controvérsias durante o seu desenvolvimento histórico, como é o caso da "hereditariedade", fortemente discutida pelos filósofos gregos por volta do ano 500 a.C.

Os filósofos da antiga Grécia divergiam quanto às explicações para a hereditariedade. Alcmeon de Crotona, um discípulo de Pitágoras de Samos [...], acreditava que homens e mulheres tinham sêmen e que este originava no cérebro. Segundo ele o sexo das crianças era determinado pela preponderância do sêmen de um dos pais, ocorrendo hermafroditismo se os estivessem em igual proporção. (AMABIS; MARTHO, 2010b, p. 17).

Essa citação ajuda a compreender que muitas explicações científicas atuais tiveram sua gênese em ideias que hoje são consideradas errôneas, contrariando, assim, a ideia de uma ciência pronta e produzida segundo uma sequência lógica de etapas, como muitas vezes é veiculada em alguns LDs.

Conforme Martins (2006, p. 19), “[ [...] os pesquisadores formulam hipóteses ou conjunturas a partir de idéias que podem não ter fundamentos [...] constroem teorias provisórias [...]" Assim, todo o conhecimento estabelecido como "verdade" é provisório até que novos estudos sejam produzidos.

No volume 3, seguem explicações dos principais filósofos da época ligados ao tema hereditariedade.

[...] denominada pangênese, cada órgão ou parte do corpo de um organismo vivo produziria partículas hereditárias chamadas de gêmulas, estas migrariam para o sêmen do macho e da fêmea e seriam transmitidas aos descendentes no momento da concep- 
ção. O novo ser seria elaborado a partir das gêmulas recebidas dos genitores, o que explicaria as semelhanças entre pais e filhos. (AMABIS; MARTHO, 2010b, p. 17).

O trecho anterior mostra que os conceitos são frutos do estado do conhecimento de determinada época, na qual foram elaborados. Segundo Fleck (1986), mesmo em diferentes interpretações persistem ideias que estabelecem conexões de dependência entre distintos modelos explicativos. Para o autor, são as proto-ideias ou pré-ideias que podem se constituir como o ponto de partida para as teorias atuais e são compreendidas como esboços históricos evolutivos e pré-científicos, e não devem ser julgadas, sob o ponto de vista atual, como corretas ou incorretas, porque pertencem a outro estilo de pensamento.

\section{VISÃO INTERNALISTA E EXTERNALISTA DA CIÊNCIA}

Ao examinar a coleção, observou-se que foi priorizada uma visão internalista da ciência. De acordo com essa visão, são enfatizados aspectos da Ciência relativos ao desenvolvimento de seus próprios objetos, leis, métodos e processos, passando uma ideia autônoma da produção do conhecimento. No trecho transcrito a seguir, nota-se que a referência ao cientista fica restrita aos seus interesses próprios pela pesquisa e pela forma pela qual a realiza.

Em 1711, o francês Louis Joblot (1645-1723) realizou um ex-
perimento no qual distribuiu, em frascos cuidadosamente lim-
pos, caldo nutritivo preparado à base de carne e previamente
fervido, de modo a matar todos os micro-organismos eventual-
mente presentes [...] Após alguns dias Joblot observou os cal-
dos dos frascos ao microscópio, num dos frascos destapados,
havia grande quantidade de micro-organismos, ausentes no
caldo dos frascos tapados. Com esse experimento, o cientista
francês acreditou ter resolvido o problema da origem dos seres
microscópicos. Ele concluiu que os micro-organismos surgiam
a partir de "sementes" provenientes do ar e não pela transfor-
mação espontânea da matéria inanimada constituinte do caldo
nutritivo. (AMABIS; MARTHO, 2010a, p. 45).

Pode-se dizer que nessa citação não estão consideradas questões de outra ordem, além da preocupação do próprio cientista na produção do conhecimento, deixando implícitos uma iniciativa e um trabalho desenvolvidos individualmente pelo próprio pesquisador, mostrando, novamente, apenas a visão internalista da Ciência, sem considerar o trabalho científico do ponto de vista coletivo. 
Nos LDs selecionados não foi observada uma discussão sobre a visão externalista da Ciência, ou seja, a influência do contexto social, político, cultural ou religioso da época na qual o conhecimento foi produzido, ou seja, quais demandas externas influenciaram a produção do conhecimento.

\section{VISÃO DE CIENTISTA}

No volume 3, há um maior número de nomes de cientistas citados comparando-se aos volumes 1 e 2 . No entanto, no volume 1 encontra-se um maior número de temas relacionados a informações históricas.

Os cientistas, apresentados nos três volumes examinados, de modo geral, caracterizam-se por suas contribuições individuais em determinado evento da Ciência. Em grande parte dos textos não há referências de como trabalhavam, quais métodos utilizaram, em qual instituição se formaram, quais as dificuldades enfrentadas, quais instrumentos utilizavam para o desenvolvimento de suas pesquisas. Dessa forma, pode-se dizer que é veiculada uma visão restrita dos cientistas e do trabalho que realizam individualmente. Para Fleck (1986), a Ciência não é uma construção formal, mas uma atividade levada a cabo por comunidades de investigadores. O conhecimento está intimamente ligado a pressupostos e condicionamentos históricos, antropológicos e culturais, relacionando-se, assim, às convicções empíricas e especulativas que unem os indivíduos. Dessa forma, não tem sentido falar sobre o trabalho de um pesquisador, mas de um coletivo.

\section{HISTÓRIA DA CIÊNCIA E A PRODUÇÃO DO CONHECIMENTO}

Quanto à forma e desenvolvimento da produção do conhecimento, se ocorre de forma linear, coletiva ou individual, com ou sem controvérsia entre os cientistas, buscamos apoio em Kuhn (2011) para uma compreensão mais adequada desses aspectos. Segundo o autor, na produção do conhecimento um paradigma estabelece os fundamentos que devem guiar a prática do pesquisador (padrões científicos, métodos, etc.). A história trazida pelos LDs acaba subtraindo parte do que realmente acontece na passagem de um paradigma para outro, transformando esse processo em um movimento linear e cumulativo, como se desde o princípio todos os cientistas caminhassem para atingir o que a Ciência é hoje, assim como os de hoje caminham linear e cumulativamente para o que será a Ciência amanhã. A passagem de um paradigma para outro, ou a transformação de um estilo de pensamento, na compreensão 
de Fleck (1986), ocorre a partir do que se denomina história descontínua por meio de transformações e rupturas, e geralmente carregada de controvérsias entre os membros da comunidade científica.

Apenas em um subtítulo do volume 2, podem-se observar "controvérsias" na produção do conhecimento científico, conforme segue:

Logo após a publicação do livro A origem das espécies pelo naturalista inglês Charles Darwin, em 1859, seu colega, Thomas H. Huxley, também um naturalista inglês, questionou-o quanto ao título e propósito da obra: Mas, em primeiro lugar, o que é uma espécie? [...] Darwin respondeu: "Nenhuma definição de espécie conseguiu, ainda, satisfazer a todos os naturalistas, embora todos eles saibam vagamente o que se quer dizer quando se fala em espécie". (AMABIS; MARTHO, 2010c, p. 23).

Na citação, Huxley contradiz Darwin em um fato que o próprio Darwin considerava desnecessário: não estava realmente preocupado com a definição precisa de espécie, pois sabia que não havia uma descrição exata que satisfizesse a todos os naturalistas, já que estes possuíam vagamente um conhecimento ou uma ideia a respeito do tema em questão.

As controvérsias ajudam o aluno a compreender que a construção do conhecimento e as ideias publicadas também geraram conflitos entre os pesquisadores e esses períodos importantes geralmente não estão presentes nos LDs.

Quanto à visão "coletiva" da produção do conhecimento, aparece em nove temas do volume 1; em quatro temas do volume 2 e em 12 temas no volume 3. Pode-se citar como exemplo o subtítulo "Caçadores de micróbios promovem avanços na medicina", presente no item "Ciência e Cidadania", em cujo texto os autores utilizam o termo "colaboradores", ao tratarem de outras pessoas ou de outros cientistas que auxiliavam Pasteur em suas pesquisas.

Depois de várias experiências malsucedidas, Pasteur e seus co-
laboradores descobriram que as lagartas sadias ficavam doentes
depois de comer as fezes ou os cadáveres de lagartas afetadas
pela doença [...] Os pesquisadores concluíram que esses glóbu-
los microscópicos eram micro-organismos parasitas, responsá-
veis pela doença. (AMABIS; MARTHO, 2010a, p. 48).

A visão "individual" da produção do conhecimento aparece em 21 temas do volume 1, em 10 temas do volume 2 e em 23 temas do volume 3.

Pode-se observar que na coleção como um todo há predominância da visão individualista do trabalho do cientista presente em 54 temas e há apenas 25 temas mostrando a visão coletiva do trabalho do cientista. 
Quanto à discussão sobre a genética, Mendel é brevemente citado, sem mencionar como e onde esse cientista realizou seu trabalho. Há um subtítulo que se refere à "Importância de Mendel para a genética". Mendel descobriu que as características hereditárias são herdadas segundo regras bem definidas e propôs uma explicação para essas regras (AMABIS; MARTHO, 2010b, p. 25).

No trecho do LD, observa-se a produção de Mendel como um trabalho individual e com informações insuficientes, para uma compreensão adequada do desenvolvimento de sua pesquisa. Leite, Ferrari e Delizoicov (2001) discutem o trabalho de Mendel mostrando o caráter coletivo de sua produção. Na maioria dos LDs, Mendel é considerado o "pai da genética", atribuindo unicamente a ele todo o processo de desenvolvimento das pesquisas e dos estudos realizados.

\section{ILUSTRAÇÕES}

As ilustrações foram examinadas visando identificar elementos/aspectos da HC nelas presentes. Nas imagens apresentadas pelos LDs, foram encontrados dois itens propostos no instrumento de pesquisa: figuras de cientistas; figuras das etapas de um experimento elou figuras de máquinas e/ou figuras de equipamentos. Dois itens não foram encontrados: modelos e figuras que relacionam o cotidiano com modelos.

Retratos de cientistas, de modo geral, trazem uma legenda com o nome do cientista, data de nascimento e falecimento e, em alguns temas, foram mencionados pequenos textos com dados sobre o trabalho científico realizado. A presença de figuras ou retratos de cientistas não foi frequente na coleção. Muitos dos textos apresentados mencionaram os cientistas, mas não apresentaram seu retrato. Em outros textos, foram mencionados mais de um cientista e não há a fotografia de nenhum deles. Na coleção, como um todo, observou-se que imagens de cientistas e/ou figuras não estavam relacionadas com modelos e/ou com o cotidiano da época.

De modo geral, pode-se dizer que a coleção de LDs examinada atende parcialmente às recomendações dos documentos oficiais para a inserção de uma perspectiva histórica na abordagem dos conteúdos, uma vez que ela está presente de forma pontual e contemplando apenas a visão internalista da Ciência.

\section{CONSIDERAÇÕES FINAIS}


O caminho percorrido na elaboração deste trabalho visou apresentar resultados de pesquisa sobre a presença da HC em LDs de Biologia do ensino médio e apontar suas características, considerando a contribuição dessa perspectiva na proposição de um ensino dinâmico, crítico e que propicie ao aluno uma compreensão mais adequada sobre a natureza da Ciência.

A análise realizada mostrou que os volumes 1 e 3 da coleção selecionada para estudo foram os que mais apresentaram aspectos e informações históricas e trechos da $\mathrm{HC}$, muitas delas com a finalidade de complementar o assunto abordado. $\mathrm{O}$ volume 2 foi o que menos contextualizou historicamente os conteúdos.

Os resultados obtidos permitiram perceber que, embora haja um avanço quanto à inserção da HC LD, pode-se dizer que ainda é tímida essa perspectiva no ensino de Biologia da coleção selecionada. Dessa forma, o professor que desejar trabalhar com a $\mathrm{HC}$ em suas aulas terá que recorrer a materiais complementares ao LD, além de se deparar com as lacunas da formação inicial para uma articulação entre HC e ensino. A afirmação é feita considerando que, de acordo com pesquisa realizada em Cursos de Licenciatura em Ciências Biológicas de Universidades situadas na região Sul do Brasil (DELIZOICOV; SLONGO; HOFFMANN, 2011), ainda é incipiente essa perspectiva na formação do professor de Biologia.

Recomenta-se que ações sejam incrementadas, como: alterações nos currículos das licenciaturas, formação continuada para os professores que estão em exercício, maior atenção dos autores de LDs em relação à articulação $\mathrm{HC}$ e ensino, além de mais incentivo para a produção de materiais de apoio ao professor, particularmente pelos pesquisadores que defendem essa perspectiva.

\section{REFERÊNCIAS}

AMABIS, J. M.; MARTHO, G. R. Biologia: Biologia das células. 3. ed. São Paulo: Moderna, 2010a. v. 1.

AMABIS, J. M.; MARTHO, G. R. Biologia: Biologia das populações. 3. ed. São Paulo: Moderna, 2010b. v. 3.

AMABIS, J. M.; MARTHO, G. R. Biologia: Biologia dos organismos. 3. ed. São Paulo: Moderna, 2010c. v. 2.

BARDIN, L. Análise de Conteúdo. Lisboa: Edições 70, 1979. 
BATISTA, R. P.; MOHR, A.; FERRARI, N. Análise da História da Ciência em Livros Didáticos do Ensino Fundamental em Santa Catarina. In: ENPEC - ENCONTRO NACIONAL DE PESQUISA EM EDUCAÇÃO EM CIÊNCIAS, 6., 2007, Florianópolis. Anais... Florianópolis: ABRAPEC, 2007.

BIZZO, N. Graves Erros de Conceito em Livros Didáticos de Ciências. Ciência Hoje, Rio de Janeiro: SBPC, v. 21, n. 121, p. 26-35, 1996.

BRASIL. Ministério da Educação e Cultura, República Federativa do Brasil. Parâmetros Curriculares Nacionais - Ensino Médio. Brasília, DF: MEC, 1997.

BRASIL. Decreto n. 91.542, de 19 de agosto de 1985. Programa Nacional do Livro Didático. Disponível em: $<$ http://www.fnde.gov.br/index.php/programas-livro-didatico>. Acesso em: 02 fev. 2012.

CARNEIRO, M. H. S.; GASTAL, M. L. História e filosofia das ciências no ensino de biologia. Ciência \& Educação, v. 1, n. 1, 2005.

CARNEIRO, M. H. S.; SANTOS, W. L. P.; MÓL, G. S. Livro Didático Inovador e Professores: uma tensão a ser vencida. Revista Ensaio-Pesquisa em Educação em Ciências, v. 7, n. 2, 2005.

DELIZOICOV, N. C. Ensino do sistema sanguíneo humano: a dimensão histórico -epistemológica. In: SILVA, C. C. (Org). Estudos de História da Ciência: Subsídios para a Aplicação no Ensino. São Paulo: Livraria da Física, 2006.

DELIZOICOV, N. C.; CARNEIRO, M. H. S.; DELIZOICOV, D. O Movimento do Sangue no Corpo Humano: do Contexto da Produção do Conhecimento para o do seu Ensino. Ciência e Educação, Bauru: Ed. Unesp, v. 10, n. 3, p. 443-460, 2004.

DELIZOICOV, N. C. O professor de Ciências Naturais e o Livro Didático (No Ensino de Programas de Saúde). Dissertação (Mestrado em Educação)-Universidade Federal de Santa Catarina, Florianópolis, 1995.

DELIZOICOV, Nadir C.; SLONGO, Iône P.; HOFFMANN, Marilisa B. História e Filosofia da Ciência e Formação de Professores: a proposição dos cursos de licenciatura em Ciências Biológicas do Sul do Brasil. Curitibba, PR: X Congresso Internacional em Educação - EDUCERE -, 2011.

EL-HANI, C. N. Notas sobre o ensino de história e filosofia da ciência na educação científica de nível superior. In: SILVA, C. C. (Org.). Estudos de história e filosofia das ciências: subsídios para aplicação no ensino. São Paulo: Livraria da Física, 2006. 
EL-HANI, C. N.; ROQUE, N.; ROCHA, P. L. B. Livros Didáticos de Biologia do Ensino Médio: Resultados do PNLEM/2007. Educação em Revista, Belo Horizonte: Ed. UFMG, v. 27, p. 211-240, 2011.

FERRARI, N.; SCHEID, N. M. J. História do DNA e Educação Científica. In: SILVA, Cibelle Celestino (Org.). Estudos de História da Ciência: Subsídios para a Aplicação no Ensino. São Paulo: Livraria da Física, 2006.

FLECK, L. La Génesis y el Desarrollo de un Hecho Científico. Madrid: Alianza Editorial, 1986.

FORATO, T. C. M.; MARTINS, R. A.; PIETROCOLA, M. Enfrentando Obstáculos na Transposição Didática da História da Ciência para a Sala de Aula. In: PEDUZZI, L. O. Q.; MARTINS, A. F.; FERREIRA, J. M. H. Temas de História e Filosofia da Ciência no Ensino. Natal: EDUFRN, 2012.

FRACALANZA, H. O que sabemos sobre os livros didáticos para o ensino de ciências no brasil. 1993. Tese (Doutorado em Metodologia de Ensino)-Universidade Estadual de Campinas, 1993.

FRISON, M. D. et al. Livro didático como instrumento de apoio para construção de propostas de ensino de Ciências naturais. Rio Grande do Sul: Ed. Unijui: Ed. UFRGS, 2009.

FUNDO NACIONAL DE DESENVOLVIMENTO DA EDUCAÇÃO. Histórico. Disponível em: <http://www.fnde.gov.br/index.php/programaslivro-didatico $>$. Acesso em: 02 fev. 2012.

GONÇALVES, P. W. Indicadores da presença de conteúdos de história e filosofia da ciência em livro de texto de geologia introdutória. Ciência \& Educação, v. 1, n. 1, 2005.

KUHN, T. S. A estrutura das revoluções científicas. Tradução Beatriz Vianna Boeira e Nelson Boeira. 10. ed. São Paulo: Perspectiva, 2011.

LEITE, R. R. C.; FERRARI, N.; DELIZOICOV, D. A história das leis de Mendel na perspectiva fleckiana. Revista da Associação Brasileira de Pesquisa em Educação em Ciências, v. 1, n. 2, p. 97-108, 2001.

MARTINS, L. A. C.; BRITO, A. P. O. P. M. A História da Ciência e o ensino de genética e evolução no nível médio: um estudo de caso. In: SILVA, C. C. (Org.). Estudos de História e Filosofia das Ciências: subsídios para aplicação no ensino. São Paulo: Livraria da Física, 2006. 
MARTINS, R. A. Introdução: A História das Ciências e seus usos na Educação. In: SILVA, C. C. (Org). Estudos de História da Ciência: Subsídios para a Aplicação no Ensino. São Paulo: Livraria da Física, 2006.

MEGID NETO, J.; FRACALANZA, H. O livro didático de Ciências: problemas e soluções. Ciência \& Educação, v. 9, n. 2, p. 147-157, 2003.

MINAYO, M. C. S.; DESLANDES, S. F.; GOMES, R. Pesquisa social: teoria, método e criatividade. 30. ed. Petrópolis: Vozes, 2011.

MOHR, A. Análise de conteúdos de saúde em livros didáticos. Ciência e Educação, Bauru: Ed. Unesp, v. 6, n. 2, p. 89-106, 2000.

OLIVEIRA, R. V.; SILVA, A. P. B. História da Ciência e Ensino de Física: uma análise meta-historiográfica. In: PEDUZZI, L. O. Q.; MARTINS, A. F.; FERREIRA, J. M. H. Temas de História e Filosofia da Ciência no Ensino. Natal: EDUFRN, 2012.

PEDUZZI, L. O. Q.; ZYLBERSZTAJN, A.; MOREIRA, M. A. As concepções espontâneas, resolução de problemas e a História da Ciência numa sequência de conteúdos em mecânica: o referencial teórico e a receptividade de estudantes universitários à abordagem histórica da relação força e movimento. Revista Brasileira de Ensino de Física, Florianópolis, v. 14, n. 4, p. 239-246, 1992.

PEDUZZI, L. O. Q.; ZYLBERSZTAJN, A.; MOREIRA, M. A. Sobre a Utilização Didática da Ciência no ensino: considerações críticas. In: PIETROCOLA M. (Org.). Ensino de Física - conteúdo, metodología e epistemología numa concepção integrada. Florianópolis: Ed. UFSC, 2001.

PEDUZZI, L. O. Q.; MARTINS, A. F. P.; FERREIRA, J. M. H. (Org.). Temas de História e Filosofia da Ciência no Ensino. Natal: EDUFRN, 2012.

PERRELLI, M. A. de S. et al. A escolha e o uso do livro didático pelos professores das áreas de ciências naturais e matemática: as pesquisas que abordam essa temática. Série-Estudos, n. 35, 2012.

PORTAL EDUCAÇÃO. Disponível em: <http://potal.mec.gov.br/index.php>. Acesso em: 02 fev. 2012.

PRETTO, N. A ciência nos livros didáticos. 2. ed. Campinas: Ed. Unicamp: Ed. da Universidade Federal da Bahia, 1985. 
ROSA, S. R. G.; SILVA, M. R. A História da Ciência nos Livros Didáticos de Biologia do Ensino Médio: uma análise do conteúdo sobre o episódio da transformação bacteriana. Alexandria Revista de Educação em Ciência e Tecnologia, v. 3, n. 2, p. 59-78, jul. 2010.

SCHEID, N. M. J.; FERRARI, N.; DELIZOICOV, D. A construção coletiva do conhecimento científico sobre a estrutura do DNA. Ciência \& Educação, v. 11, n. 2, p. 223-233, 2005.

SECRETARIA DE EDUCAÇÃO BÁSICA. Guia de livros Didáticos PNDL 2012 Biologia. Brasília, DF: Ministério da Educação, 2011.

SILVA, C. B. C.; OLIVEIRA, A. C. Como os livros didáticos de Biologia abordam as diferentes formas de estimar a biodiversidade? Ciência \& Educação, v. 19, n. 1, 2013.

SLONGO, I. I. P. História da Ciência e Ensino: contribuições para a formação do professor de Biologia. 1996. Dissertação. CED/PPGE, Universidade Federal de Santa Catarina, Florianópolis, 1996.

SUTTON, C. Beliefs about science and beliefs about language. International Journal of Science Education, London, v. 18, n. 1, p. 1-18, 1996.

ZANETIC, J. Mesa Redonda: Influência da História de Ciência no Ensino de Física. In: Caderno Catarinense de Ensino de Física, Florianópolis, v. 5, p. 76-92, 1998. Edição Especial. 
